\title{
Strong Genetic Differentiation Between North American and European Populations of Phytophthora alni subsp. uniformis
}

\author{
Jaime Aguayo, Gerard C. Adams, Fabien Halkett, Mursel Catal, Claude Husson, \\ Zoltán Á. Nagy, Everett M. Hansen, Benoît Marçais, and Pascal Frey
}

First, third, fifth, eighth, and ninth authors: INRA, UMR1136, INRA, Université de Lorraine, Interactions Arbres-Micro-organismes, IFR110 EFABA, Centre INRA de Nancy, 54280 Champenoux, France; second author: Department of Plant Pathology, University of Nebraska, Lincoln; fourth author: Department of Plant Protection, Akdeniz University, Antalya, Turkey; sixth author: Plant Protection Institute, Centre for Agricultural Research, Hungarian Academy of Sciences, Budapest, Hungary; and seventh author: Department of Botany and Plant Pathology, Oregon State University, Corvallis.

Accepted for publication 15 October 2012.

\begin{abstract}
Aguayo, J., Adams, G. C., Halkett, F., Catal, M., Husson, C., Nagy, Z. Á., Hansen, E. M., Marçais, B., and Frey, P. 2013. Strong genetic differentiation between North American and European populations of Phytophthora alni subsp. uniformis. Phytopathology 103:190-199.

Alder decline caused by Phytophthora alni has been one of the most important diseases of natural ecosystems in Europe during the last 20 years. The emergence of $P$. alni subsp. alni - the pathogen responsible for the epidemic - is linked to an interspecific hybridization event between two parental species: P. alni subsp. multiformis and P. alni subsp. uniformis. One of the parental species, $P$. alni subsp. uniformis, has been isolated in several European countries and, recently, in North America. The

mating system of $P$. alni subsp. uniformis. Five new polymorphic microsatellite markers were used to contrast both geographical populations. The study comprised 71 isolates of $P$. alni subsp. uniformis collected from eight European countries and 10 locations in North America. Our results revealed strong differences between continental populations $(F \mathrm{st}=$ $0.88 ; R$ st $=0.74$ ), with no evidence for gene flow. European isolates showed extremely low genetic diversity compared with the North American collection. Selfing appears to be the predominant mating system in both continental collections. The results suggest that the European P. alni subsp. uniformis population is most likely alien and derives from the introduction of a few individuals, whereas the North American population probably is an indigenous population.
\end{abstract} objective of this work was to assess the level of genetic diversity, the population genetic structure, and the putative reproduction mode and

Diseases that increase in severity or expand their range pose important threats to natural ecosystems $(4,17,45)$. Although the emergence of disease can be the result of changes in host or environmental conditions, or evolution in pathogen populations (4), the introduction of exotic pathogens has been shown to be a major cause $(4,16,17,46)$. However, assessing whether the causal organism of an emerging disease is alien is not always straightforward $(43,56)$. This results mostly from a lack of knowledge and data on the biodiversity and ecology of endemic species $(17,43)$. For example, in the genus Phytophthora, low genetic variability has often been taken as an indication that specific populations are exotic (see Phytophthora quercina [13], P. nemorosa, $P$. pseudosyringae [56], and $P$. pinifolia [22]). Indeed, introduction into a new geographical area often results in a population with low variability $(36,72)$ because founder effects caused by the migration of a limited number of individuals result in reduced gene diversity and number of alleles in introduced populations (55). However, low variability cannot be taken as definite proof of the exotic nature of a population as long as the diversity center has not been identified $(33,43)$. Low genetic variability may occur in a native population, especially when selfing is suspected. It is noteworthy that many Phytophthora spp. are homothallic and reproduce mainly by selfing $(33,43)$. Self-fertilization will impact population genetic characteristics by increasing linkage disequilibrium (LD) and reducing genetic diversity $(33,43)$. Con-

Corresponding author: P. Frey; E-mail address: frey@nancy.inra.fr

http://dx.doi.org/10.1094/PHYTO-05-12-0116-R

(c) 2013 The American Phytopathological Society
Additional keywords: Alnus, oomycetes. versely, some alien populations display high levels of genetic diversity $(30,54)$ as a result of multiple introductions $(15,18)$. Indeed, to study the genetic changes that may have occurred during and after an introduction event, it is important to identify the source of the introduction with as much precision as possible. Moreover, knowledge of the mode of reproduction (sexual versus asexual) and the mating system (selfing versus outcrossing) is of fundamental importance to the evolutionary biology of pathogens $(6,34)$. The reproduction mode and the mating system will affect how diversity is distributed within and among individuals in a population (60), and supply insights into the potential of pathogens to spread and on their ability to evolve (33). Indeed, in Phytophthora spp., asexual (zoospores) and sexual (oospores) propagules exhibit contrasted dispersal and survival abilities, with strong epidemiological consequences. The source region will provide the benchmark against which genetic and evolutionary changes can be assessed, representing the variation from which the introduction was actually derived (18). For example, for $P$. cinnamomi, Papua New Guinea has been proposed as the center of origin $(19,36)$. Indeed, this population presented a higher allelic diversity compared with other populations $(19,36)$. However, determining the center of origin of a species is not always obvious. In the case of $P$. infestans, two possible centers of origin have been proposed: either Central Mexico (37) or the Andean region of South America (35).

Alder decline caused by the $P$. alni species complex is a good example of poorly understood pathogen emergence in a natural ecosystem $(24,76)$. This disease has posed a major threat to natural ecosystems in Europe during the last 20 years (74). For example, in eastern France, disease prevalence has reached 17\% 
of riparian alder (Alnus glutinosa) trees (76). The emergence of this disease is linked to an interspecific hybridization event $(9,47)$. Recent studies have clarified the genesis of the interspecific hybrid $P$. alni subsp. alni. $P$. alni subsp. uniformis and $P$. alni subsp. multiformis, initially identified as genetic variants of $P$. alni subsp. alni (9), were shown to be the parental species of the hybrid (47). The hybrid $P$. alni subsp. alni is more aggressive than its progenitors and is responsible for disease outbreak (73). However, it is not known when and where hybridization took place. Moreover, the origin of the parental species, $P$. alni subsp. uniformis and $P$. alni subsp. multiformis, remains unknown. $P$. alni subsp. alni is widespread in Europe and has not been identified elsewhere. Although P. alni subsp. multiformis has been isolated exclusively in Europe, $P$. alni subsp. uniformis has been isolated both in Europe and, recently, in North America.

The present work constitutes the first population genetics study of one of the parental species of the hybrid $P$. alni subsp. alni. The objectives of this work were to assess the level of genetic diversity, the population genetic structure, and the putative reproduction mode of North American and European populations of P. alni subsp. uniformis. To this end, we characterized the population structure of two continental collections using new polymorphic microsatellite markers developed for this study.

\section{MATERIALS AND METHODS}

Isolate collection and DNA extraction. $P$. alni subsp. uniformis isolates used in this study are listed in Table 1. European $P$. alni subsp. uniformis isolates were obtained after several field campaigns during the years 1999, 2005, 2008, and 2009. Surveys were carried out in 111 sites across northern France, the Wallonia region of Belgium, and in Hungary. Additional P. alni subsp. uniformis isolates were obtained from colleagues elsewhere in Europe (Table 1; Fig. 1). North American isolates were collected between the years 2008 and 2012 after a survey of 81 sites across south-central and interior Alaska (1), and Oregon (Fig. 1). Isolates were obtained from collar bark and necrotic root tissues of infected alders and from in situ baiting. Samples were collected from different diseased trees to minimize the risk of sampling the same individual twice. Alder bark and root pieces were placed on V8 juice agar selective medium for Phytophthora spp. (27), and growing mycelium was transferred to fresh V8 juice agar medium containing rifampicin (10 mg/liter) as soon as detected. For in situ baiting, rhododendron (Azalea spp.) and bearberry (Arctostaphylos uva-ursi) leaves and thinleaf alder twigs (Alnus incana subsp. tenuifolia) were used. As lesions appeared, isolates were transferred to V8 juice agar selective medium. Colonies were subcultured and maintained as above.

DNA was extracted from 4-day-old pure fresh mycelia grown on V8 juice agar medium using a BioSprint 96 DNA plant kit (Qiagen, Courtaboeuf, France) in combination with a BioSprint 96 automated workstation (Qiagen) following the BS-96DNAplant protocol, or using a Qiagen DNeasy Plant Mini Kit according to the supplier's instructions. Species identification was based on the DNA sequence homology of the internal transcribed spacer and using species-specific primers designed against the nuclear genes $R A S$-Ypt and TRP1, following the protocol of Ioos et al. (47).

For microsatellite development, DNA was extracted from 5-day-old colonies of isolates PAU60, PAU320, and PA340 grown in liquid V8 medium containing rifampicin $(10 \mathrm{mg} / \mathrm{liter})$ at $20^{\circ} \mathrm{C}$ using the Qiagen DNeasy Plant Mini Kit as described above.

Microsatellite development. Microsatellite markers were developed using an enriched library generated with a Roche GSFLX Titanium pyrosequencing platform. The three lots of DNA extracted from PAU60, PAU320, and PA340 were mixed, and DNA quantity was estimated with a NanoDrop 1000 Spectrophotometer (NanoDrop Technologies, Wilmington, DE). The en- richment step, data analysis, and automated primer design were described previously by Malausa et al. (58). The enriched microsatellite library generated a total of 34,483 microsatellite sequences, with 550 putative microsatellite loci identified. Choice of microsatellite loci for further tests was constrained to motifs of $\geq 2 \mathrm{bp}$ in length and a minimum repeat number of 5 . Using these criteria, 110 loci were further retained. These 110 primer pairs were tested for amplification on a panel of $10 P$. alni subsp. uniformis, 10 P. alni subsp. multiformis, and 5 P. alni subsp. alni European isolates. No North American P. alni subsp. uniformis isolates were available when loci were tested. Microsatellite loci were amplified in a GeneAmp polymerase chain reaction (PCR) System 9700 Thermal Cycler (Applied Biosystems, Foster City, CA) under the following conditions: an initial denaturing step of $5 \mathrm{~min}$ at $95^{\circ} \mathrm{C} ; 35$ cycles, including $30 \mathrm{~s}$ of initial denaturing at $94^{\circ} \mathrm{C}, 90 \mathrm{~s}$ of annealing at $60^{\circ} \mathrm{C}$, and $60 \mathrm{~s}$ of extension at $72^{\circ} \mathrm{C}$; and a 30 -min final extension step at $60^{\circ} \mathrm{C}$. A PCR mix was prepared using the Type-it Microsatellite PCR kit in a $12-\mu l$ final reaction volume containing $2 \mu \mathrm{l}$ of DNA, $5 \mu \mathrm{l}$ of $2 \times$ Type-it mix, $1 \mu \mathrm{l}$ of $5 \times \mathrm{Q}$-solution, $0.2 \mathrm{mM}$ reverse primer, $0.02 \mathrm{mM} \mathrm{M} 13-$ tailed forward primer, and $0.2 \mathrm{mM}$ fluorescence-labeled M13 primer (5'-CACGACGTTGTAAAACGAC-3'). Amplified PCR products were loaded on an ABI 3730 Genetic Analyzer (Applied Biosystems). Fragments were sized with a LIZ-1200 size standard. Alleles were scored using GeneMapper 4.0 (Applied Biosystems). Loci that showed allelic polymorphism, expected peak size, and correct peak amplification were kept for subsequent tests. Forward primers for the selected perfect microsatellite loci were labeled with a fluorescent tag (FAM, NED, VIC, or PET). PCR conditions for genotyping the $71 P$. alni subsp. uniformis isolates were as described above. PCR was conducted using the Type-it Microsatellite PCR kit in a $12-\mu$ final reaction volume containing $2 \mu \mathrm{l}$ of DNA, $5 \mu \mathrm{l}$ of $2 \times$ Type-it mix, $1 \mu \mathrm{l}$ of $5 \times$ Q-solution, and $0.2 \mu \mathrm{M}$ each reverse and forward primers. Six multiplex PCR were run, comprising one to three loci each. PCR products from these multiplex reactions were pooled into two mixes according to their fluorescent tag color and size, and analyzed as described above. Genotyping was replicated for a subset of isolates with independent PCR reactions and sizing of fragments. Reproducibility of molecular data was confirmed.

Data analysis. Global analysis. To examine the relationships among isolates, a matrix of genotype distances was constructed with the Polysat R-package (12) using the genetic distance of Bruvo (10). This distance is similar to band-sharing indices used with dominant data but takes into account mutational distances between alleles. The result is a distance ranging from 0 to 1 , with 0 indicating identical genotypes and 1 being a theoretical maximum distance if all alleles from one genotype differed by an infinite number of repeats from all alleles in another genotype. A nonmetric multidimensional scaling (MDS) for two axes was then performed (59). In MDS, a small number of axes are chosen explicitly prior to the analysis, and the data are fitted to those dimensions, so that there are no hidden axes of variation. Alternatively, we computed the shared allele distance $\left(D_{\mathrm{as}}\right)(51)$ using the Populations 1.2.31 program (O. Langella; http://bioinformatics.org/ tryphon/populations/). These kinds of clustering have the important advantage over other clustering methods, such as Bayesian clustering algorithms, that no underlying assumptions such as Hardy-Weinberg (HW) equilibrium or absence of LD between loci are required $(52,61)$. The concordance between the Bruvo and the $\mathrm{D}_{\text {as }}$ distances was tested by Mantel tests $\left(\mathrm{H}_{0}=\right.$ matrices are not correlated) with 10,000 permutations. Estimation of global and across-loci $F$ st (based on allele identity under infinite allele model) and $R$ st (based on microsatellite allele size under stepwise-mutation model) between the European and North American collections were computed according to Weir and Cockerham (78) and Rousset (70) for Fst and Rst estimates, respectively, using SPAGEDI (44). The GENECLASS 2 program 
TABLE 1. List of the Phytophthora alni subsp. uniformis isolates used in this study and multilocus genotype (MLG) assignation for each isolate

\begin{tabular}{|c|c|c|c|c|c|c|}
\hline Isolate & Supplier & Reference $^{\mathrm{a}}$ & Country & Location & Isolation year & $\mathrm{MLG}^{\mathrm{b}}$ \\
\hline PAU768 & G. Adams & QC Bowl 8A & United States (Alaska) & Quartz Creek & 2010 & A5 \\
\hline PAU769 & G. Adams & QC Bowl 10 & United States (Alaska) & Quartz Creek & 2010 & A6 \\
\hline PAU770 & G. Adams & QC Bowl 12 & United States (Alaska) & Quartz Creek & 2010 & A1 \\
\hline PAU846 & G. Adams & PAU420 / Gen-7 Bowl-2 1-2 & United States (Alaska) & Quartz Creek & 2009 & A2 \\
\hline PAU772 & G. Adams & CLBow19B & United States (Alaska) & Cooper Landing & 2010 & A3 \\
\hline PAU773 & G. Adams & CLb8 & United States (Alaska) & Cooper Landing & 2010 & A3 \\
\hline PAU845 & G. Adams & PAU330 / Gen-9 Bowl-4 1-1 & United States (Alaska) & Cooper Landing & 2009 & A3 \\
\hline PAU776 & G. Adams & BLb9 & United States (Alaska) & Birch Lake & 2010 & A1 \\
\hline PAU825 & G. Adams & BLR15-3 & United States (Alaska) & Birch Lake & 2011 & A1 \\
\hline PAU826 & G. Adams & DC30T1-2 & United States (Alaska) & Birch Lake & 2011 & A1 \\
\hline PAU836 & G. Adams & BLR30-3 & United States (Alaska) & Birch Lake & 2011 & A1 \\
\hline PAU837 & G. Adams & DC30T3 & United States (Alaska) & Dave's Creek & 2011 & A1 \\
\hline PAU843 & G. Adams & PAU290 / Gen 3-B2- 2-1 & United States (Alaska) & Dave's Creek & 2009 & A2 \\
\hline PAU844 & G. Adams & PAU291 / Gen 3-B2- 3-4 & United States (Alaska) & Dave's Creek & 2009 & A7 \\
\hline PAU848 & G. Adams & PAU95 / stem 60-60- 7/9-3-1 & United States (Alaska) & Fairbanks & 2009 & $\mathrm{~A} 1$ \\
\hline PAU815 & E. Hansen & 118-R-IK.1 & United States (Oregon) & Yachats & 2011 & A1 \\
\hline PAU816 & E. Hansen & 118-R-IJ.3 & United States (Oregon) & Yachats & 2011 & A1 \\
\hline PAU817 & E. Hansen & 118-R-IJ.4 & United States (Oregon) & Yachats & 2011 & A1 \\
\hline PAU849 & E. Hansen & 110-R-IN-1 & United States (Oregon) & Reedsport & 2012 & A1 \\
\hline PAU187 & D. de Merlier & 2276 & Belgium & Mons & 2001 & E1 \\
\hline PAU188 & D. de Merlier & 2277 & Belgium & Habay-la-Neuve & 2001 & E1 \\
\hline PAU558 & J. Aguayo & $\ldots$ & Belgium & Harmignies & 2009 & E1 \\
\hline PAU561 & J. Aguayo & $\ldots$ & Belgium & Harmignies & 2009 & E1 \\
\hline PAU87 & D. de Merlier & 2271 & Belgium & Ligneuville & 2001 & E1 \\
\hline PAU302 & C. Husson & $\ldots$ & France & Baerendorf & 2008 & E1 \\
\hline PAU320 & O. Caël & $\ldots$ & France & Baerendorf & 2008 & E1 \\
\hline PAU368 & O. Caël & $\ldots$ & France & Baerendorf & 2009 & E1 \\
\hline PAU529 & R. Ioos & $\ldots$ & France & Métairies-Saint-Quirin & 2005 & E1 \\
\hline PAU530 & R. Ioos & $\ldots$ & France & Métairies-Saint-Quirin & 2005 & E1 \\
\hline PAU531 & R. Ioos & $\ldots$ & France & Métairies-Saint-Quirin & 2005 & E1 \\
\hline PAU624 & J. Aguayo & $\ldots$ & France & Métairies-Saint-Quirin & 2009 & E3 \\
\hline PAU625 & J. Aguayo & $\ldots$ & France & Métairies-Saint-Quirin & 2009 & E1 \\
\hline PAU626 & J. Aguayo & $\ldots$ & France & Métairies-Saint-Quirin & 2009 & E1 \\
\hline PAU627 & J. Aguayo & $\ldots$ & France & Métairies-Saint-Quirin & 2009 & E1 \\
\hline PAU628 & J. Aguayo & $\ldots$ & France & Métairies-Saint-Quirin & 2009 & E1 \\
\hline PAU629 & J. Aguayo & $\ldots$ & France & Métairies-Saint-Quirin & 2009 & E1 \\
\hline PAU630 & J. Aguayo & $\ldots$ & France & Métairies-Saint-Quirin & 2009 & E1 \\
\hline PAU632 & J. Aguayo & $\ldots$ & France & Métairies-Saint-Quirin & 2009 & E1 \\
\hline PAU633 & J. Aguayo & $\ldots$ & France & Métairies-Saint-Quirin & 2009 & E1 \\
\hline PAU333 & O. Caël & $\ldots$ & France & Wingen-sur-Moder & 2008 & E1 \\
\hline PAU538 & J. Aguayo & $\ldots$ & France & Wingen-sur-Moder & 2009 & E1 \\
\hline PAU539 & J. Aguayo & $\ldots$ & France & Wingen-sur-Moder & 2009 & E1 \\
\hline PAU300 & C. Husson & & France & Wolfskirchen & 2008 & E1 \\
\hline PAU808 & S. Werres & BBA $7 / 03$ & Germany & - & 2002 & E1 \\
\hline PAU811 & S. Werres & BBA70434 & Germany & _- & 1997 & E1 \\
\hline PAU668 & Z. Nagy & $155-\mathrm{a}$ & Hungary & Hanság & 1999 & E1 \\
\hline PAU669 & Z. Nagy & 155-b, CBS117377 & Hungary & Hanság & 1999 & E1 \\
\hline PAU670 & Z. Nagy & $155-\mathrm{c}$ & Hungary & Hanság & 1999 & E1 \\
\hline PAU89 & P. Capretti & $\mathrm{Ph} 68, \mathrm{CBS} 109280, \mathrm{P} 1234^{*}$ & Italy & Northern Tuscany & 2000 & $\mathrm{E} 2$ \\
\hline PAU142 & A. Munda & Phy-A-Slo & Slovenia & Ljubljana & 2003 & E1 \\
\hline PAU780 & C. Pintos-Varela & $685 \mathrm{~A}$ & Spain & Ribadavia & 2009 & E1 \\
\hline PAU84 & C. Olsson & CH161/P875* & Sweden & Gothenburg & 1996 & $\mathrm{E} 2$ \\
\hline PAU807 & C. Olsson & $\mathrm{CH} 162$ & Sweden & Gothenburg & 1996 & E1 \\
\hline
\end{tabular}

a Original code for the isolates; * indicates reference isolates in Brasier et al. (9).

${ }^{\mathrm{b}}$ P. alni subsp. uniformis MLG assignation for each isolate. 
(65) was used to detect first-generation migrants. The test uses a Monte-Carlo resampling method that identifies statistical thresholds beyond which individuals are likely to be $\mathrm{F}_{0}$ immigrants (64). The goal of this test is to distinguish between residents that have a genotype that is most likely to occur in a population other than the one in which the individual was sampled by chance, and $\mathrm{F}_{0}$ immigrants that are misassigned because they originated somewhere other than where they were sampled (64). Additionally, to study the relationship among genotypes, a minimum spanning network (MSN) was constructed using the Bruvo's distance. MINSPNET (26) was used to create the network, which was visualized using the NEATO program in the GRAPHVIZ package (32).

Within-continent characterization. Identification of multilocus genotypes (MLGs) was performed using a Visual Basic module developed by Goyeau et al. (40). This procedure, designed specially to deal with clonal organisms, allows the identification of MLGs, scoring the number of variant alleles. Clonal richness, $R=G-1 / N-1$ (20) was computed (with $G=$ number of MLGs found and $N=$ sample size). Clonal evenness $(V)$-an index that reflects equitability in the distribution of clonal membership among samples-was computed using GENCLONE 1.0 (5). Clonal richness and clonal evenness indices reflect the extent of clonal reproduction in populations $(5,42)$. Genotypic diversity $\left(\mathrm{D}_{\mathrm{g}}\right)$ was computed with MULTILOCUS 1.3 (2). This index is independent of clonal richness and can be defined as the probability that two individuals taken at random have different MLGs. The allelic richness (Ar) — an index that represents the number of alleles corrected for sample size (25) - and the expected and observed heterozygosities were computed with
FSTAT 2.9.3.2 (39). Fisher's exact tests were run to test the significance of genetic differentiation and Ar. Fisher's exact tests were used because they are robust when the number of individuals is low $(40,68)$. Because clonal amplification of genotypes could influence data interpretation, analyses of genetic structure should be performed with and without repeated identical MLGs $(42,75)$. Indeed, when duplicate MLGs are removed, rare alleles that distinguish MLGs have increased weight in the analysis. This may also underrepresent common alleles, because identical MLGs, composed of identical common alleles, can be expected to occur by chance following recombination. On the other hand, if duplicate MLGs are not removed, a single individual may be represented several times in the data set if asexual reproduction occurs (49). Thus, all the following indices were computed considering both all individuals and one representative isolate of each MLG per sampling site (referred to as the "MLG data set"). Departure from HW equilibrium was studied by two methods. First, global tests using the complete enumeration method (57), well adapted for low numbers of alleles by locus, were performed using GENEPOP (68). Because an exact $P$ value is computed by complete enumeration, no standard value is calculated. The null hypothesis tested was a random union of gametes. Second, unbiased estimates of $F$ is (78) and $R$ is (70) were computed with SPAGEDI.

LD was assessed by two approaches. First, we studied the significance of non-random association or gametic disequilibrium among pairs of loci for each population. This test looks for the association between diploid genotypes at both loci. For a pair of diploid loci, no assumption is made about the gametic phase in

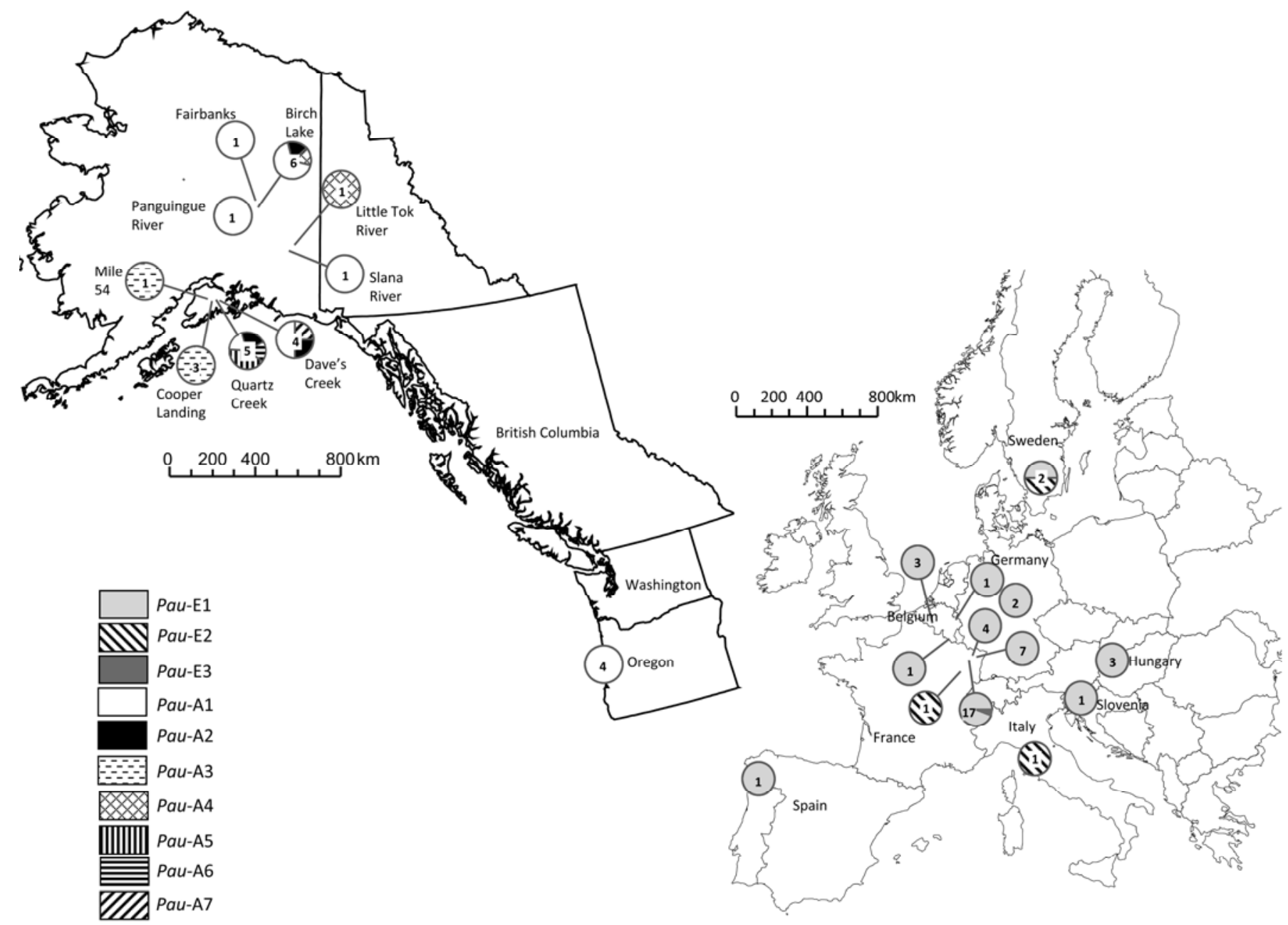

Fig. 1. Location of the sampling sites in North America and Europe, and spatial distribution of Phytophthora alni subsp. uniformis multilocus genotypes. Numbers inside the pie charts indicate the sample size for each location. 
double heterozygotes (particularly in HW equilibrium). The test was performed with GENEPOP, considering as null hypothesis that genotypes at one locus are independent of genotypes at the other locus. The default test statistic was the log likelihood ratio statistic ( $\mathrm{G}$ test). Contingency tables were created for all pairs of loci in each sample, and then a $G$ test was computed for each table using a Markov chain algorithm (68). Second, using MULTILOCUS 1.3, we computed the measure of multilocus LD, $\bar{r}_{\mathrm{s}}$-an alternative measure of multilocus LD that analyzes the allelic values directly and sums over all individuals. The analysis is similar to a two-way analysis of variance (ANOVA) on allelic values, which tests for a significant between-individual effect. Because $P$ values are obtained from randomizations, no assumption of normality is associated generally with ANOVA tests. This index was computed by bootstrapping alleles 1,000 times among individuals, independently for each locus.

Mantel tests were performed to test the significance of the correlation between geographical or temporal and genetic distances. First, a matrix of Euclidean pairwise geographical distances was built for both European and North American collections. Second, in order to check the temporal genetic structure, a pairwise matrix of the differences between sampling years was computed. A normalized Mantel statistic was obtained by combining the binary matrix describing the geographical or temporal relationships and the corresponding Bruvo's genetic distances. All tests were performed for all the isolates and the MLG data set with 10,000 permutations.

\section{RESULTS}

Sample collection and species identification. Surveys in alder stands in France, Belgium, and Hungary allowed us to isolate 34
P. alni subsp. uniformis from a total of $516 P$. alni sensu lato isolates (6.6\%). Among these P. alni subsp. uniformis isolates, $50 \%$ were collected from one single site (Métairies-Saint-Quirin) in northeastern France. Ten other isolates were obtained from colleagues in other European locations (Table 1; Fig. 1). In North America, the yield was approximately one $P$. alni subsp. uniformis isolate per 100 Phytophthora colonies. Neither P. alni subsp. alni nor $P$. alni subsp. multiformis were isolated from North American sites. PCR amplification with species-specific primers for nuclear genes $R A S$-Ypt and TRP1 confirmed the $P$. alni subsp. uniformis status of all isolates (data not shown). In total, 71 isolates (44 from Europe and 27 from North America) were analyzed in this study.

Microsatellite development. Among the 110 microsatellite loci tested, 37 (33.6\%) amplified as expected. Among these loci, $32(86 \%)$ were monomorphic and $5(14 \%)$ were polymorphic in $P$. alni subsp. uniformis, with 2 to 3 alleles per locus and an average of 1.5 alleles per locus (Table 2). Only one locus was informative among European isolates (M-PAU3), whereas three loci exhibited some polymorphism within North American isolates (M-PAU3, M-PAU9, and M-PAU55). All five loci were highly informative to discriminate between continental collections (Table 3).

Between-continent genetic analysis. Genotyping of the 71 $P$. alni subsp. uniformis isolates permitted their assignment into 10 MLGs, including 7 from North America and 3 from Europe (Table 3). No MLGs were shared between the North American and European collections. The European collection exhibited one major MLG (Pau-E1, 91\% of the isolates) and two minor MLGs (Pau-E2 and Pau-E3). The 27 North American isolates were distributed into 7 MLGs (Table 3). MLG Pau-A1 was dominant in North America, accounting for $50 \%$ of the isolates. Private alleles

TABLE 2. Characteristics of the microsatellite markers used in this study

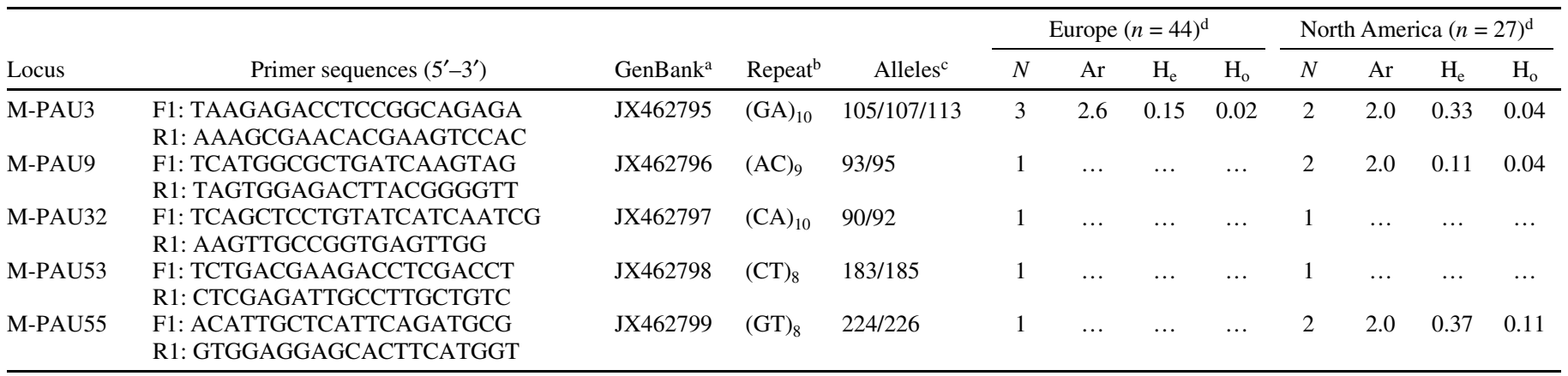

${ }^{a}$ GenBank accession number.

${ }^{\mathrm{b}}$ Repeat motif.

c Alleles observed per locus.

d Abbreviations: $n=$ number of individuals per collection, $N=$ number of alleles observed by collection, $\mathrm{Ar}=$ allelic richness per locus, $\mathrm{H}_{\mathrm{e}}=$ mean expected heterozygosity per locus, and $\mathrm{H}_{\mathrm{o}}=$ mean observed heterozygosity per locus.

TABLE 3. Multilocus genotypes (MLGs) identified for the European and North American collections of Phytophthora alni subsp. uniformis

\begin{tabular}{|c|c|c|c|c|c|c|c|}
\hline $\mathrm{MLG}^{\mathrm{a}}$ & $N^{\mathrm{b}}$ & Isolates $(\%)$ & M-PAU3 & M-PAU9 & M-PAU32 & M-PAU53 & M-PAU55 \\
\hline Рau-E1 & 40 & 90.9 & 107/107 & $93 / 93$ & $92 / 92$ & $185 / 185$ & $226 / 226$ \\
\hline Рau-E2 & 3 & 6.8 & 113/113 & $93 / 93$ & 92/92 & $185 / 185$ & $226 / 226$ \\
\hline Раu-E3 & 1 & 2.3 & 105/107 & $93 / 93$ & 92/92 & $185 / 185$ & $226 / 226$ \\
\hline Раи-A1 & 14 & 51.9 & 107/107 & $95 / 95$ & $90 / 90$ & $183 / 183$ & $226 / 226$ \\
\hline Раи-A2 & 4 & 14.8 & 107/107 & $95 / 95$ & $90 / 90$ & $183 / 183$ & $224 / 224$ \\
\hline Раи-A3 & 4 & 14.8 & $105 / 105$ & $95 / 95$ & $90 / 90$ & $183 / 183$ & $226 / 226$ \\
\hline Раи-A4 & 2 & 7.4 & 107/107 & 95/95 & $90 / 90$ & $183 / 183$ & $224 / 226$ \\
\hline Раи-A7 & 1 & 3.7 & 105/107 & 95/95 & $90 / 90$ & $183 / 183$ & $224 / 224$ \\
\hline Total North America & 27 & $\ldots$ & $\ldots$ & $\ldots$ & $\ldots$ & $\ldots$ & $\ldots$ \\
\hline
\end{tabular}

a P. alni subsp. uniformis MLG.

${ }^{\mathrm{b}}$ Number of individuals per MLG. 
were observed between continental collections (Table 4). Four alleles were shared by isolates from the two collections, four alleles were unique to the North American isolates, and three alleles were unique to the European isolates.

The MDS performed using Bruvo's distance between isolates clearly differentiated the European and North American collections (Fig. 2). A similar pattern was obtained when $\mathrm{D}_{\mathrm{as}}$ distance was used (data not shown). This was confirmed by a Mantel test which indicated that both distances were significantly correlated $(r=0.90, P<0.001)$. Consistently, high global $F$ st $(F$ st $=0.88$; $P<0.001)$ and $R$ st $(R \mathrm{st}=0.74 ; P<0.001)$ values were found between both collections. Significant $F$ st and $R$ st values were obtained for all loci (Table 5). Indices computed for the MLG data set showed the same pattern, with high and significant global and across loci $F$ st $(F$ st $=0.82 ; P<0.001)$ and $R$ st $(R$ st $=0.63 ; P<$ 0.001 ) values (Table 5). Tests performed with GENECLASS did not detect any first-generation migrants in either population. The MSN (Fig. 3) showed that the European cluster was linked to the North American cluster by a Bruvo distance of 0.125 between the MLGs Pau-E1 and Pau-A5. This distance was larger than the range of distances among MLGs within both North America (0.034 to 0.045$)$ and Europe (0.045 to 0.068$)$, possibly indicating lack of sampling of missing intermediate genotypes.

TABLE 4. Private alleles and allele frequency detected for European and North American collections

\begin{tabular}{lcccccc}
\hline & \multicolumn{2}{c}{ Europe } & & \multicolumn{2}{c}{ North America } \\
\cline { 2 - 3 } \cline { 5 - 6 } Locus & Allele & Frequency & & Allele & Frequency \\
\hline M-PAU3 & 113 & 0.068 & & $\ldots$ & $\ldots$ \\
M-PAU9 & $\ldots$ & $\ldots$ & & 95 & 0.944 \\
M-PAU32 & 92 & 1.000 & & 90 & 1.000 \\
M-PAU53 & 185 & 1.000 & & 183 & 1.000 \\
M-PAU55 & $\ldots$ & $\ldots$ & & 224 & 0.240 \\
\hline
\end{tabular}

Within-continent genetic analysis. The gene diversity $\left(\mathrm{H}_{\mathrm{e}}\right)$ per locus for all isolates ranged from $\mathrm{H}_{\mathrm{e}}=0$ to $\mathrm{H}_{\mathrm{e}}=0.37$, with an average gene diversity value of $\mathrm{H}_{\mathrm{e}}=0.16 \pm 0.16$ and $\mathrm{H}_{\mathrm{e}}=0.03 \pm$ 0.07 for the North American and European isolates, respectively (mean \pm standard deviation [SD]) (Table 6). Observed heterozygosity $\left(\mathrm{H}_{\mathrm{o}}\right)$ for all isolates ranged from $\mathrm{H}_{\mathrm{o}}=0$ to $\mathrm{H}_{\mathrm{o}}=0.1$, with an average value of $\mathrm{H}_{\mathrm{o}}=0.04 \pm 0.04$ for the North American collection and $\mathrm{H}_{\mathrm{o}}=0.004 \pm 0.01$ for the European collection (mean $\pm \mathrm{SD}$ ) (Table 6). Clonal richness $(R)$, genotypic diversity $\left(D_{\mathrm{g}}\right)$, and evenness $(V)$ were low for the European collection $(R=$ $\left.0.05, D_{\mathrm{g}}=0.17, V=0.14\right)$ compared with the North American collection $\left(R=0.23, D_{\mathrm{g}}=0.74, V=0.62\right)$ (Table 6). Both collections exhibited significant deviation from HW proportions $(P<$ 0.001 for both collections,). Similar results were obtained for the MLG data set $(P=0.003$ and $P<0.001$ for the European and the North American MLG data sets, respectively). Consistently, global $F$ is and $R$ is estimates computed for all individuals and for the MLG data set were positive and significant (Table 6). The $\mathrm{Ar}$

TABLE 5. Global and per locus Fst and Rst between European and North American populations of Phytophthora alni subsp. uniformis ${ }^{\mathrm{a}}$

\begin{tabular}{lccccc}
\hline & \multicolumn{2}{c}{$F$ st } & & \multicolumn{2}{c}{$R$ st } \\
\cline { 2 - 3 } \cline { 5 - 6 } Locus & $\begin{array}{c}\text { All individuals } \\
(n=71)\end{array}$ & $\begin{array}{c}\text { MLG } \\
(n=37)\end{array}$ & & $\begin{array}{c}\text { All individuals } \\
(n=71)\end{array}$ & $\begin{array}{c}\text { MLG } \\
(n=37)\end{array}$ \\
\hline Per locus & & & & & \\
M-PAU3 & $0.09^{*}$ & $0.03^{*}$ & & $0.13^{*}$ & $0.18^{*}$ \\
M-PAU9 & $0.95^{*}$ & $0.91^{*}$ & & $0.95^{*}$ & $0.91^{*}$ \\
M-PAU32 & $1.00^{*}$ & $1.00^{*}$ & & $1.00^{*}$ & $1.00^{*}$ \\
M-PAU53 & $1.00^{*}$ & $1.00^{*}$ & & $1.00^{*}$ & $1.00^{*}$ \\
M-PAU55 & $0.27^{*}$ & $0.30^{*}$ & & $0.27^{*}$ & $0.30^{*}$ \\
Multilocus & $0.88^{*}$ & $0.82^{*}$ & $0.74^{*}$ & $0.63^{*}$ \\
\hline${ }^{a}$ MLG $=$ multilocus genotype and * indicates statistically significant $(P<$ \\
\multicolumn{2}{c}{$0.05)}$.
\end{tabular}

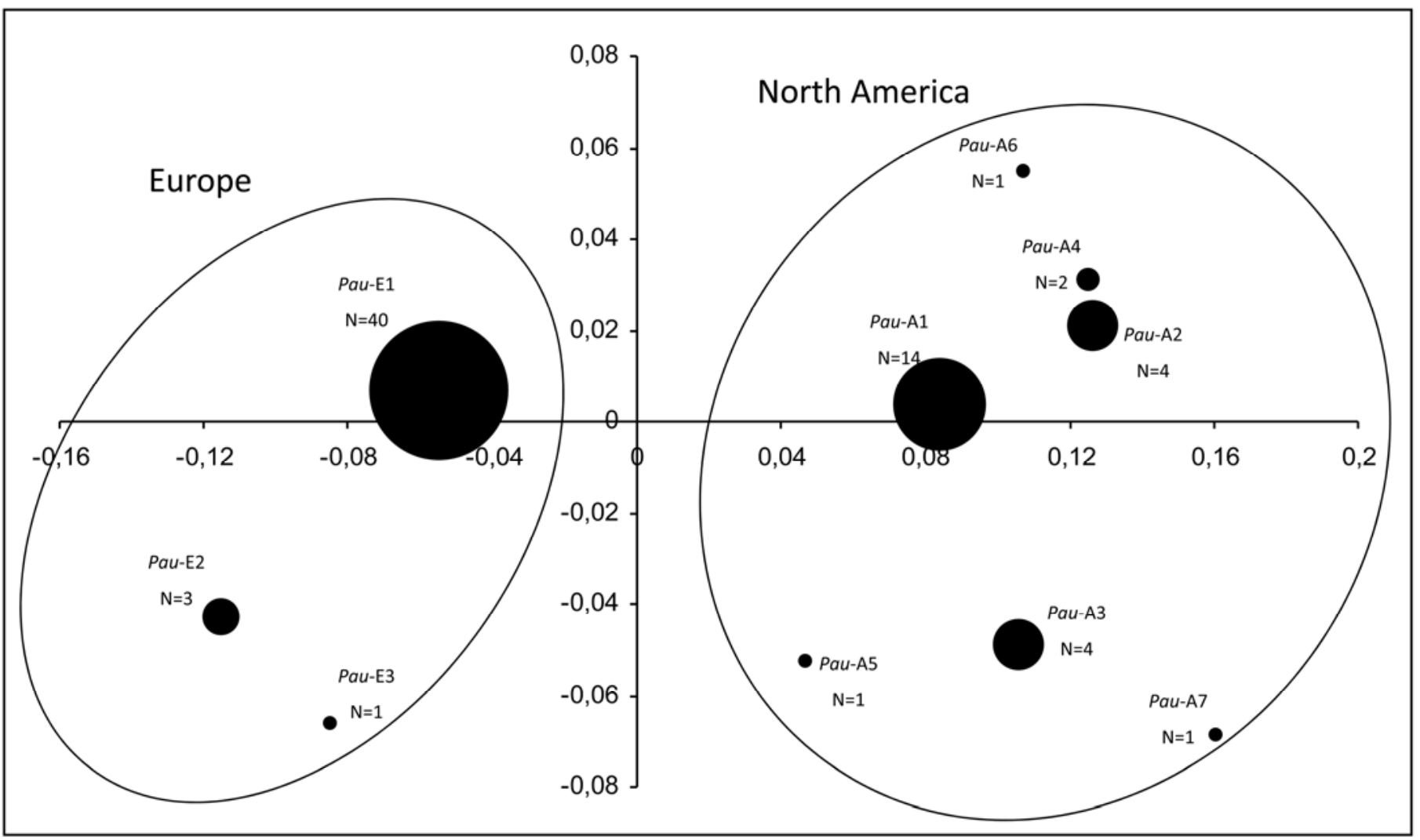

Fig. 2. Nonmetric multidimensional scaling for two axes of Phytophthora alni subsp. uniformis multilocus genotypes (MLGs) on the basis of the Bruvo's distance. Circle areas are proportional to the number of individuals, except for MLGs Pau-E1 and Pau-A1. 
corrected for 27 isolates was higher for the North American collection compared with the European collection $(P<0.001)$. This difference was lower and not significant when computed for the MLG data set $(P>0.05)$.
Examination of LD by correlation between pairs of loci revealed complete dependence among all pairs of loci for the European collection. For the North American collection, when tests could be performed, zero of three pairs of loci exhibited no

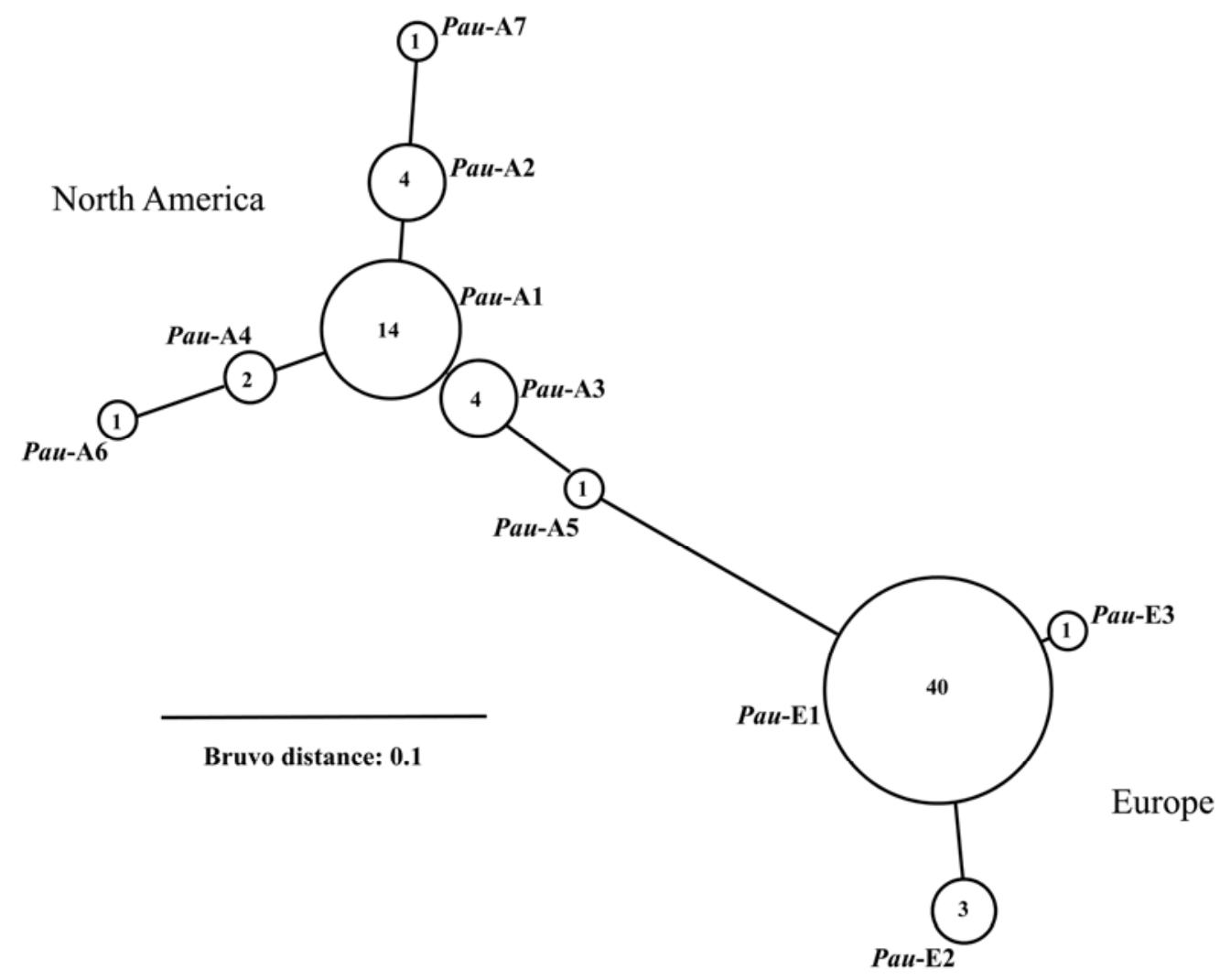

Fig. 3. Minimum spanning network showing the relationships among the 10 multilocus genotypes (MLGs) found in Europe and North America. Branch sizes are proportional to Bruvo's genetic distance, and surface areas of the circles are proportional to the numbers of isolates in each MLG (indicated inside the circles). Names of the MLGs are indicated.

TABLE 6. Comparison of the genetic structure of North American and European populations of Phytophthora alni subsp. uniformis revealed by microsatellite markers ${ }^{\mathrm{a}}$

\begin{tabular}{|c|c|c|c|c|}
\hline \multirow[b]{2}{*}{ Statistics ${ }^{\mathrm{b}}$, locus } & \multicolumn{2}{|c|}{ North America } & \multicolumn{2}{|c|}{ Europe } \\
\hline & All individuals $(n=27)$ & $\operatorname{MLG}(n=17)$ & All individuals $(n=44)$ & $\operatorname{MLG}(n=20)$ \\
\hline$R$ & 0.37 & $\mathrm{nc}$ & 0.05 & $\mathrm{nc}$ \\
\hline V & 0.74 & $\mathrm{nc}$ & 0.14 & $\mathrm{nc}$ \\
\hline $\mathrm{H}_{\mathrm{e}}^{2}$ & $0.16( \pm 0.16)$ & $0.19( \pm 0.19)$ & $0.03( \pm 0.07)$ & $0.10( \pm 0.23)$ \\
\hline $\mathrm{H}_{\mathrm{o}}$ & $0.04( \pm 0.04)$ & $0.06( \pm 0.10)$ & $0.004( \pm 0.01)$ & $0.02( \pm 0.04)$ \\
\hline $\mathrm{Ar}$ & $1.60( \pm 0.55)$ & $1.60( \pm 0.55)$ & $1.32( \pm 0.72)$ & $1.38( \pm 0.85)$ \\
\hline M-PAU3 & 0.73 & $1.00 *$ & $0.85^{*}$ & $0.81 *$ \\
\hline M-PAU9 & 0.67 & 0.64 & $\mathrm{nc}$ & $\mathrm{nc}$ \\
\hline M-PAU32 & $\mathrm{nc}$ & $\mathrm{nc}$ & $\mathrm{nc}$ & $\mathrm{nc}$ \\
\hline M-PAU53 & $\mathrm{nc}$ & $\mathrm{nc}$ & $\mathrm{nc}$ & $\mathrm{nc}$ \\
\hline M-PAU55 & $0.72 *$ & 0.26 & $\mathrm{nc}$ & $\mathrm{nc}$ \\
\hline$F$ is multilocus & $0.71 *$ & $0.62 *$ & $0.85^{*}$ & $0.81 *$ \\
\hline M-PAU55 & 0.71 & 0.62 & $\mathrm{nc}$ & $\mathrm{nc}$ \\
\hline$R$ is multilocus & $0.78^{*}$ & $0.67 *$ & $0.85 *$ & $0.84^{*}$ \\
\hline
\end{tabular}

${ }^{a}$ When possible, statistics were computed considering all individuals, or multilocus genotype MLG dataset only; nc $=$ cannot be computed and $*=$ statistically significant $(P<0.05)$.

${ }^{\mathrm{b}} R=$ clonal richness, $V=$ clonal evenness, $D_{\mathrm{g}}=$ genotypic diversity, $\mathrm{H}_{\mathrm{e}}=$ unbiased expected heterozygosity $($ mean \pm standard deviation $[\mathrm{SD}]), \mathrm{H}_{\mathrm{o}}=$ observed heterozygosity $($ mean $\pm \mathrm{SD}), \mathrm{Ar}=$ allelic richness (mean $\pm \mathrm{SD}), \mathrm{LD}=$ pairwise linkage disequilibrium, and $\bar{r}_{\mathrm{s}}=$ multilocus linkage disequilibrium. 
pairwise LD when all individuals were considered. The same results were obtained for both collections when the MLG data set was considered (Table 6 ). The $\bar{r}_{\mathrm{s}}$ multilocus estimate of LD computed for the North American collection was negative and not significant $\left(\bar{r}_{\mathrm{s}}=-0.04 ; P=0.82\right)$. Similar results were obtained for the North American MLG data set $\left(\bar{r}_{\mathrm{s}}=-0.01 ; P=0.90\right)$. For the European isolates, $\bar{r}_{\mathrm{s}}$ could not be computed, because polymorphism was extremely low and determined only by one locus, suggesting complete linkage across loci.

The geographical distribution of the MLGs for European and North American isolates are shown in Figure 1. Mantel tests showed no evidence for spatial structure in either collections $(r=$ $0.09, P=0.19$ for the European collection and $r=-0.11, P=0.99$ for the North American collection). The MLG data set exhibited similar results $(r=-0.15, P=0.39$ for the European collection and $r=-0.19, P=0.84$ for the North American collection). No evidence for temporal structure in the genetic diversity was found in either collections ( $r=0.040, P=0.27$ for the European collection and $r=-0.26, P=0.99$ for the North American collection). The same pattern was found when tests were performed for the MLG data set $(r=0.013, P=0.35$ and $r=-0.24, P=0.87$ for the European and for the North American MLG data sets, respectively).

\section{DISCUSSION}

Isolate sampling and microsatellite development. Isolate collection for this study accounted for more than 10 years of field work in Europe and North America. The low recovery rate of $P$. alni subsp. uniformis is in accordance with the published literature (53). The low number of polymorphic loci found and the low number of alleles per locus are consistent with results obtained for other oomycetes $(19,66,71,77)$. Thus, the use of a highthroughput methodology involving pyrosequencing of a microsatellite-enriched library yielded results comparable with those found by Ioos et al. (48) on P. alni subsp. alni using the classical method of cloning and sequencing of a microsatellite-enriched DNA library. This low number of polymorphic microsatellites in $P$. alni subsp. uniformis is in accordance with results of Dutech et al. (23), who showed that obtaining microsatellite markers with an acceptable level of polymorphism is generally more difficult from fungi and oomycetes than from other organisms.

Genetic characterization of North American and European P. alni subsp. uniformis. North American P. alni subsp. uniformis exhibited a moderate genotypic diversity and evenness. Our data suggest that selfing is probably the predominant mating system of North American P. alni subsp. uniformis. Indeed, the population exhibited significant deviation from HW proportions and high global $F$ is and $R$ is values, as expected for a homothallic organism $(3,21,29,36)$. Self-fertilization has frequently been considered important in homothallic oomycetes (36). However, strict selfing cannot explain the diversity exhibited by the North American population. Self-fertilization reduces the amount of heterozygosity by one-half in every generation; thus, there should be almost no heterozygosity in homothallic Phytophthora spp. that have been established for more than a few generations (36). This was not the case for North American P. alni subsp. uniformis, which exhibited gene diversity similar to heterothallic, outcrossing oomycetes $(36,41)$. Moreover, our results did not show complete LD, suggesting that the genetic structure of North American populations of $P$. alni subsp. uniformis can be explained by a mixed mating system, including selfing and, probably, rare outcrosses. Indeed, it has been shown that outcrossing is important in generating and maintaining variation in homothallic oomycetes $(28,29,41)$. However, the balance between selfing and outcrosses is not easy to establish, and may be dynamic and highly dependent on spatiotemporal conditions (34).

The genetic characteristics of the European collection of $P$. alni subsp. uniformis were different from the North American popu- lation. Although northeastern France is over-represented in our sampling, we have studied $P$. alni subsp. uniformis isolates from eight different countries scattered throughout Europe, and the extremely low genotypic diversity and evenness across large areas and different environmental conditions is significant. All the variation observed in Europe was attributed to a single locus (M-PAU3). However, the reproductive mode and the mating system of European P. alni subsp. uniformis are less clear than that of North American P. alni subsp. uniformis. Low genotypic diversity and gene diversity, coupled with high and significant $F$ is and $R$ is values, and the strong LD detected for all loci tested suggest that the European $P$. alni subsp. uniformis are selfing. However, strict clonality after a strong bottleneck resulting from an introduction of $P$. alni subsp. uniformis in Europe cannot be rejected. This has been described for other pandemics of plant pathogens that were subjected to strong founder effects after introduction $(37,38,50,67)$. The possibility of sexual reproduction in Europe would have some important epidemiological consequences, such as the production of resistant spores $(24,53)$. Delcán and Brasier (14) showed that European P. alni subsp. uniformis were able to produce viable oospores in controlled laboratory conditions, although germination was not observed. However, in vitro observations do not allow strong inferences regarding the reproductive mode in natural conditions (6).

Neither population exhibited any spatial or temporal structure. This can be explained by the existence of an efficient longdistance dispersal means through rivers. Moreover, in Europe, planting of seedlings from infected nurseries has been shown to be an important mechanism of long-distance spread (53). This may explain the widespread occurrence of $P$. alni subsp. uniformis in Europe.

Genetic differences between North American and European populations of $\boldsymbol{P}$. alni subsp. uniformis. Our study revealed strong differences between the American and European collections of $P$. alni subsp. uniformis (global $F$ st $=0.89$ and $R$ st $=$ 0.74). The genetic differentiation between collections was caused by the presence of private alleles within each population. No evidence of gene flow could be detected between populations. Such high levels of genetic differentiation within one species have already been reported $(63,69)$, and could be caused by genetic drift through founder effects accompanying the spread of the disease, which may result in strongly differentiated populations (69). Furthermore, the mating system (predominantly selfing) of $P$. alni subsp. uniformis is likely to reinforce the genetic structure between continental populations, because selfing will tend to decrease the effective population size (11).

We hypothesize that $P$. alni subsp. uniformis is likely to be alien in Europe, and may have derived from the introduction of only a few individuals, whereas the American population of $P$. alni subsp. uniformis is probably indigenous. The differentiation between collections is large and does not point to a North American origin of the European P. alni subsp. uniformis (large Fst and Rst, presence of private alleles, and no evidence of first-generation migrants in either collection). However, a North American origin of European P. alni subsp. uniformis remains possible. A single connection between both collections visualized with the computed MSN suggests a single and not a multiple introduction of $P$. alni subsp. uniformis in Europe from a putative North American source population. However, the MSN indicates that some intermediate genotypes were missing. Indeed, sampling in North America was not exhaustive and, thus, private alleles observed in Europe could well have been missed in this limited sample.

Concluding remarks. This study provides new insights into the origin of the interspecific hybrid $P$. alni subsp. alni, which is primarily responsible for the outbreak of alder decline in Europe. The origin of $P$. alni subsp. alni could be explained by three nonexclusive scenarios: (i) a recent hybridization event directly following the introduction of one (or two) of the parental species, 
$P$. alni subsp. uniformis and $P$. alni subsp. multiformis; (ii) longtime coexistence of both parental species which, after the apparition of favorable environmental conditions (e.g., climatic conditions), would have succeeded in mating in nature; or (iii) an ancient hybridization event giving raise to $P$. alni subsp. alni, followed by a long coexistence of $P$. alni subsp. alni, $P$. alni subsp. uniformis, and $P$. alni subsp. multiformis, and a recent emergence of the $P$. alni subsp. alni-induced alder decline triggered by more favorable environmental conditions. Our results suggest that the introduction of $P$. alni subsp. uniformis would have enabled hybridization with $P$. alni subsp. multiformis and, consequently, may be a major cause of the emergence of alder decline in Europe. However, when and where the P. alni subsp. uniformis invasion and subsequent hybridization took place, and its recurrence, remain unknown. Moreover, whether $P$. alni subsp. multiformis is exotic or indigenous to Europe is also an open question. It seems that $P$. alni subsp. alni may have arisen after multiple hybridizations of the parental species in alder nurseries used for riparian restoration projects in Europe $(33,47,53)$. Further studies in population genetics and epidemiology of $P$. alni subsp. alni, P. alni subsp. uniformis, and P. alni subsp. multiformis are needed to address these hypotheses.

Species involved in interspecific hybridization need to meet some genetic criteria and to share the same environment for successful hybridization to occur (62). The genetic barriers to hybridization are weaker in phylogenetically close species that have evolved in allopatry (7). Therefore, the chances of interspecific hybridization increase when two allopatric species accidentally come into secondary contact $(7,8,62)$, as probably occurred for $P$. alni subsp. alni. The risk of hybridization between previously allopatric pathogen species is likely to increase as the international trade of plant material intensifies, and their associated pathogens are introduced into new geographical areas $(8,31)$.

\section{ACKNOWLEDGMENTS}

B. Marçais and P. Frey co-directed this work. This research was funded by a grant of the Région Lorraine (France), the Agence Nationale de la Recherche (ANR 07-BDIV-003, Emerfundis program), the European Union (Interreg IV A Ecolirimed program and Cost action FP0801 "PhytoThreat"), and the Comisión Nacional de Investigación Científica y Tecnológica de Chile (Conicyt, Chile). We thank O. Caël, B. Bertin, and A. Chandelier for their help in collecting French and Belgian samples; A. Andrieux for her technical support in microsatellite development and isolate genotyping; L. Trummer, L. Winton, and crew members J. Chille and G. Black (United States Department of Agriculture Forest Service region 10, Anchorage, Alaska) for field assistance in obtaining Alaskan isolates of $P$. alni subsp. uniformis; L. Sims (Oregon State University) for assistance in checking field disease characteristics, and isolate collection and identification; our European colleagues (see Table 1) for sharing $P$. alni subsp. uniformis isolates with us; T. Malausa (INRA, Sophia-Antipolis) for having included $P$. alni subsp. uniformis in his project of highthroughput microsatellite isolation through pyrosequencing; and two anonymous reviewers for their helpful comments on an earlier version of this article.

\section{LITERATURE CITED}

1. Adams, G. C., Catal, M., and Trummer, L. M. 2009. Distribution and severity of Alder Phytophthora in Alaska. Pages 29-49 in: Proc. Sudden Oak Death Fourth Sci. Symp. For. Serv. Gen. Tech. Rep. PSW-GTR-229. Department of Agriculture, Albany, CA.

2. Agapow, P.-M., and Burt, A. 2001. Indices of multilocus linkage disequilibrium. Mol. Ecol. Notes 1:101-102.

3. Ahmed, S., de Labrouhe, D. T., and Delmotte, F. 2012. Emerging virulence arising from hybridisation facilitated by multiple introductions of the sunflower downy mildew pathogen Plasmopara halstedii. Fungal Genet. Biol. 49:847-855.

4. Anderson, P. K., Cunningham, A. A., Patel, N. G., Morales, F. J., Epstein, P. R., and Daszak, P. 2004. Emerging infectious diseases of plants: Pathogen pollution, climate change and agrotechnology drivers. Trends Ecol. Evol. 19:535-544.
5. Arnaud-Haond, S., and Belkhir, K. 2007. GENCLONE: a computer program to analyse genotypic data, test for clonality and describe spatial clonal organization. Mol. Ecol. Notes 7:15-17.

6. Billiard, S., López-Villavicencio, M., Hood, M. E., and Giraud, T. 2012. Sex, outcrossing and mating types: unsolved questions in fungi and beyond. J. Evol. Biol. 25:1020-1038.

7. Brasier, C. M. 1995. Episodic selection as a force in fungal microevolution, with special reference to clonal speciation and hybrid introgression. Can. J. Bot. 73:1213-1221.

8. Brasier, C. M. 2001. Rapid evolution of introduced plant pathogens via interspecific hybridization. BioScience 51:123-133.

9. Brasier, C. M., Kirk, S. A., Delcán, J., Cooke, D. E. L., Jung, T., and Man In't Veld, W. A. 2004. Phytophthora alni sp. nov. and its variants: designation of emerging heteroploid hybrid pathogens spreading on Alnus trees. Mycol. Res. 108:1172-1184.

10. Bruvo, R., Michiels, N. K., D’Souza, T. G., and Schulenburg, H. 2004. A simple method for the calculation of microsatellite genotype distances irrespective of ploidy level. Mol. Ecol. 13:2101-2106.

11. Charlesworth, D. 2003. Effects of inbreeding on the genetic diversity of populations. Philos. Trans. R. Soc. Lond. Ser. B. 358:1051-1070.

12. Clark, L. V., and Jasieniuk, M. 2011. POLYSAT: an R package for polyploid microsatellite analysis. Mol. Ecol. Resour. 11:562-566.

13. Cooke, D. E. L., Jung, T., Williams, N. A., Schubert, R., Oßwald, W., and Duncan, J. M. 2005. Genetic diversity of European populations of the oak fine-root pathogen Phytophthora quercina. For. Pathol. 35:57-70.

14. Delcán, J., and Brasier, C. M. 2001. Oospore viability and variation in zoospore and hyphal tip derivatives of the hybrid alder Phytophthoras. For. Pathol. 31:65-83.

15. Delmotte, F., Giresse, X., Richard-Cervera, S., M'Baya, J., Vear, F., Tourvieille, J., Walser, P., and de Labrouhe, D. T. 2008. Single nucleotide polymorphisms reveal multiple introductions into France of Plasmopara halstedii, the plant pathogen causing sunflower downy mildew. Infect. Genet. Evol. 8:534-540.

16. Desprez-Loustau, M.-L., Courtecuisse, R., Robin, C., Husson, C., Moreau, P.-A., Blancard, D., Selosse, M.-A., Lung-Escarmant, B., Piou, D., and Sache, I. 2010. Species diversity and drivers of spread of alien fungi (sensu lato) in Europe with a particular focus on France. Biol. Invas. 12:157-172.

17. Desprez-Loustau, M.-L., Robin, C., Buée, M., Courtecuisse, R., Garbaye, J., Suffert, F., Sache, I., and Rizzo, D. M 2007. The fungal dimension of biological invasions. Trends Ecol. Evol. 22:472-480.

18. Dlugosch, K. M., and Parker, I. M. 2008. Founding events in species invasions: Genetic variation, adaptive evolution, and the role of multiple introductions. Mol. Ecol. 17:431-449.

19. Dobrowolski, M. P., Tommerup, I. C., Shearer, B. L., and O'Brien, P. A. 2003. Three clonal lineages of Phytophthora cinnamomi in Australia revealed by microsatellites. Phytopathology 93:695-704.

20. Dorken, M. E., and Eckert, C. G. 2001. Severely reduced sexual reproduction in northern populations of a clonal plant, Decodon verticillatus (Lythraceae). J. Ecol. 89:339-350.

21. Dorrance, A., and Grünwald, N. J. 2008. Phytophthora sojae: Diversity among and within populations. Pages 197-212 in: Oomycete Genetics and Genomics: Diversity, Interactions, and Research Tools. K. Lamour and S. Kamoun, eds. John Wiley \& Sons, Inc., Hoboken, NJ.

22. Durán, A., Gryzenhout, M., Drenth, A., Slippers, B., Ahumada, R., Wingfield, B. D., and Wingfield, M. J. 2010. AFLP analysis reveals a clonal population of Phytophthora pinifolia in Chile. Fungal Biol. 114:746-752.

23. Dutech, C., Enjalbert, J., Fournier, E., Delmotte, F., Barrès, B., Carlier, J., Tharreau, D., and Giraud, T. 2007. Challenges of microsatellite isolation in fungi. Fungal Genet. Biol. 44:933-949.

24. Elegbede, C. F., Pierrat, J.-C., Aguayo, J., Husson, C., Halkett, F., and Marçais, B. 2010. A statistical model to detect asymptomatic infectious individuals with an application in the Phytophthora alni-induced alder decline. Phytopathology 100:1262-1269.

25. Excoffier, L., and Heckel, G. 2006. Computer programs for population genetics data analysis: a survival guide. Nat. Rev. Genet. 7:745-758.

26. Excoffier, L., and Smouse, P. E. 1994. Using allele frequencies and geographic subdivision to reconstruct gene trees within a species: molecular variance parsimony. Genetics 136:343-359.

27. Ferguson, A. J., and Jeffers, S. N. 1999. Detecting multiple species of Phytophthora in container mixes from ornamental crop nurseries. Plant Dis. 83:1129-1136.

28. Forster, H., Tyler, B. M., and Coffey, M. D. 1994. Phytophthora sojae races have arisen by clonal evolution and by rare outcrosses. Mol. PlantMicrobe Interact. 7:780-791.

29. Francis, D. M., and Clair, D. A. S. 1997. Population genetics of Pythium ultimum. Phytopathology 87:454-461.

30. Frankham, R. 2004. Resolving the genetic paradox in invasive species. Heredity 94:385-385. 
31. Frey, P. 2009. L'hybridation interspécifique chez les champignons phytopathogènes à l'origine de nouvelles maladies. BioFutur 28:36-39.

32. Gansner, E. R., and North, S. C. 2000. An open graph visualization system and its applications to software engineering. Software Pract. Exp. 30:1203-1233.

33. Garbelotto, M. 2008. Molecular analysis to study invasions by forest pathogens: Examples from Mediterranean ecosystems. Phytopathol. Mediterr. 47:183-203.

34. Giraud, T., Enjalbert, J., Fournier, E., Delmotte, F., and Dutech, C. 2008. Population genetics of fungal diseases of plants. Parasite 15:449-454.

35. Gómez-Alpizar, L., Carbone, I., and Ristaino, J. B. 2007. An Andean origin of Phytophthora infestans inferred from mitochondrial and nuclear gene genealogies. Proc. Natl. Acad. Sci. USA 104:3306-3311.

36. Goodwin, S. B. 1997. The population genetics of Phytophthora. Phytopathology 87:462-473.

37. Goodwin, S. B., Cohen, B. A., and Fry, W. E. 1994. Panglobal distribution of a single clonal lineage of the Irish potato famine fungus. Proc. Natl. Acad. Sci. USA 91:11591-11595.

38. Goss, E. M., Carbone, I., and Grünwald, N. J. 2009. Ancient isolation and independent evolution of the three clonal lineages of the exotic sudden oak death pathogen Phytophthora ramorum. Mol. Ecol. 18:1161-1174.

39. Goudet, J. 1995. FSTAT (version 1.2): A computer program to calculate F statistics. J. Hered. 86:485-486.

40. Goyeau, H., Halkett, F., Zapater, M.-F., Carlier, J., and Lannou, C. 2007. Clonality and host selection in the wheat pathogenic fungus Puccinia triticina. Fungal Genet. Biol. 44:474-483.

41. Grünwald, N. J., and Hoheisel, G. A. 2006. Hierarchical analysis of diversity, selfing, and genetic differentiation in populations of the oomycete Aphanomyces euteiches. Phytopathology 96:1134-1141.

42. Halkett, F., Simon, J.-C., and Balloux, F. 2005. Tackling the population genetics of clonal and partially clonal organisms. Trends Ecol. Evol. 20:194-201.

43. Hansen, E. M. 2008. Alien forest pathogens: Phytophthora species are changing world forests. Boreal Environ. Res. 13:33-41.

44. Hardy, O. J., and Vekemans, X. 2002. SPAGEDI: A versatile computer program to analyse spatial genetic structure at the individual or population levels. Mol. Ecol. Notes 2:618-620.

45. Harvell, C. D., Mitchell, C. E., Ward, J. R., Altizer, S., Dobson, A. P., Ostfeld, R. S., and Samuel, M. D. 2002. Climate warming and disease risks for terrestrial and marine biota. Science 296:2158-2162.

46. Husson, C., Scala, B., Caël, O., Frey, P., Feau, N., Ioos, R., and Marçais, B. 2011. Chalara fraxinea is an invasive pathogen in France. Eur. J. Plant Pathol. 130:311-324.

47. Ioos, R., Andrieux, A., Marçais, B., and Frey, P. 2006. Genetic characterization of the natural hybrid species Phytophthora alni as inferred from nuclear and mitochondrial DNA analyses. Fungal Genet. Biol. 43:511529.

48. Ioos, R., Barrès, B., Andrieux, A., and Frey, P. 2007. Characterization of microsatellite markers in the interspecific hybrid Phytophthora alni ssp. alni, and cross-amplification with related taxa. Mol. Ecol. Notes 7:133137.

49. Ivey, C. T., and Richards, J. T. 2001. Genetic diversity of everglades sawgrass, Cladium jamaicense (Cyperaceae). Int. J. Plant Sci. 4:817-825.

50. Ivors, K., Garbelotto, M., Vries, I. D. E., Ruyter-Spira, C., Hekkert, B. T., Rosenzweig, N., and Bonants, P. 2006. Microsatellite markers identify three lineages of Phytophthora ramorum in US nurseries, yet single lineages in US forest and European nursery populations. Mol. Ecol. 15:1493-1505.

51. Jin, L., and Chakraborty, R. 1994. Estimation of genetic distance and coefficient of gene diversity from single-probe multilocus DNA fingerprinting data. Mol. Biol. Evol. 11:120-127.

52. Jombart, T., Pontier, D., and Dufour, A. B. 2009. Genetic markers in the playground of multivariate analysis. Heredity 102:330-341.

53. Jung, T., and Blaschke, M. 2004. Phytophthora root and collar rot of alders in Bavaria: distribution, modes of spread and possible management strategies. Plant Pathol. 53:197-208

54. Kolbe, J. J., Glor, R. E., Rodriguez Schettino, L., Lara, A. C., Larson, A., and Losos, J. B. 2004. Genetic variation increases during biological invasion by a Cuban lizard. Nature 431:177-181.

55. Linde, C. C., Liles, J. A., and Thrall, P. H. 2010. Expansion of genetic diversity in randomly mating founder populations of Alternaria brassicicola infecting Cakile maritima in Australia. Appl. Environ. Microbiol. 76:1946-1954.

56. Linzer, R. E., Rizzo, D. M., Cacciola, S. O., and Garbelotto, M. 2009. AFLPs detect low genetic diversity for Phytophthora nemorosa and $P$. pseudosyringae in the US and Europe. Mycol. Res. 113:298-307.
57. Louis, E. J., and Dempster, E. 1987. An exact test for Hardy-Weinberg and multiple alleles. Biometrics 43:805-811.

58. Malausa, T., Gilles, A., Meglécz, E., Blanquart, H., Duthoy, S., Costedoat, C., Dubut, V., Pech, N., Castagnone-Sereno, P., Délye, C., Feau, N., Frey, P., Gauthier, P., Guillemaud, T., Hazard, L., Le Corre, V., LungEscarmant, B., Malé, P.-J., Ferreira, S., and Martin, J.-F. 2011. Highthroughput microsatellite isolation through 454 GS-FLX Titanium pyrosequencing of enriched DNA libraries. Mol. Ecol. Resour. 11:638-644.

59. Mascheretti, S., Croucher, P. J. P., Kozanitas, M., Baker, L., and Garbelotto, M. 2009. Genetic epidemiology of the sudden oak death pathogen Phytophthora ramorum in California. Mol. Ecol. 18:4577-4590.

60. McDonald, B. A., and Linde, C. 2002. Pathogen population genetics, evolutionary potential, and durable resistance. Annu. Rev. Phytopathol. 40:349-379.

61. Montarry, J., Andrivon, D., Glais, I., Corbiere, R., Mialdea, G., and Delmotte, F. 2010. Microsatellite markers reveal two admixed genetic groups and an ongoing displacement within the French population of the invasive plant pathogen Phytophthora infestans. Mol. Ecol. 19:19651977.

62. Olson, Å., and Stenlid, J. 2002. Pathogenic fungal species hybrids infecting plants. Microbes Infect. 4:1353-1359.

63. Ordoñez, M. E., and Kolmer, J. A. 2007. Simple sequence repeat diversity of a worldwide collection of Puccinia triticina from durum wheat. Phytopathology 97:574-583.

64. Paetkau, D., Slade, R., Burden, M., and Estoup, A. 2004. Genetic assignment methods for the direct, real-time estimation of migration rate: A simulation-based exploration of accuracy and power. Mol. Ecol. 13:5565.

65. Piry, S., Alapetite, A., Cornuet, J. M., Paetkau, D., Baudouin, L., and Estoup, A. 2004. GENECLASS2: A software for genetic assignment and first-generation migrant detection. J. Hered. 95:536-539.

66. Prospero, S., Black, J. A., and Winton, L. M. 2004. Isolation and characterization of microsatellite markers in Phytophthora ramorum, the causal agent of sudden oak death. Mol. Ecol. Notes 4:672-674.

67. Raboin, L. M., Selvi, A., Oliveira, K. M., Paulet, F., Calatayud, C., Zapater, M. F., Brottier, P., Luzaran, R., Garsmeur, O., Carlier, J., and D'Hont, A. 2007. Evidence for the dispersal of a unique lineage from Asia to America and Africa in the sugarcane fungal pathogen Ustilago scitaminea. Fungal Genet. Biol. 44:64-76.

68. Raymond, M., and Rousset, F. 1995. GENEPOP (Version 1.2): Population genetics software for exact tests and ecumenicism. J. Hered. 86:248-249.

69. Rivas, G.-G., Zapater, M.-F., Abadie, C., and Carlier, J. 2004. Founder effects and stochastic dispersal at the continental scale of the fungal pathogen of bananas Mycosphaerella fijiensis. Mol. Ecol. 13:471-482.

70. Rousset, F. 1996. Equilibrium values of measures of population subdivision for stepwise mutation processes. Genetics 142:1357-1362.

71. Rouxel, M., Papura, D., Nogueira, M., Machefer, V., Dezette, D., RichardCervera, S., Carrere, S., Mestre, P., and Delmotte, F. 2012. Microsatellite markers for the characterization of native and introduced populations of Plasmopara viticola, the causal agent of grapevine downy mildew. Appl. Environ. Microbiol. 78:6337-6340.

72. Sakai, A. K., Allendorf, F. W., Holt, J. S., Lodge, D. M., Molofsky, J., With, K. A., Baughman, S., Cabin, R. J., Cohen, J. E., Ellstrand, N. C., McCauley, D. E., O'Neil, P., Parker, I. M., Thompson, J. N., and Weller, S. G. 2001. The population biology of invasive species. Annu. Rev. Ecol. Syst. 32:305-332.

73. Santini, A., Barzanti, G. P., and Capretti, P. 2003. Susceptibility of some mesophilic hardwoods to alder Phytophthora. J. Phytopathol. 151:406410.

74. Streito, J. C. 2003. Phytophthora disease of alder: Identification and distribution. Pages 25-38 in: Phytophthora Disease of Alder in Europe. J. N. Gibbs, C. van Dijk, and J. Webber, eds. Forestry Commission Bulletin 126, Forestry Commission, Edinburgh, UK.

75. Sunnucks, P., De Barro, P. J., Lushai, G., MacLean, N., and Hales, D. 1997. Genetic structure of an aphid studied using microsatellites: Cyclic parthenogenesis, differentiated lineages and host specialization. Mol. Ecol. 6:1059-1073.

76. Thoirain, B., Husson, C., and Marçais, B. 2007. Risk factors for the Phytophthora-induced decline of alder in northeastern France. Phytopathology 97:99-105.

77. Trigiano, R. N., Wadl, P. A., Dean, D., Hadziabdic, D., Scheffler, B. E., Runge, F., Telle, S., Thines, M., Ristaino, J., and Spring, O. 2012. Ten polymorphic microsatellite loci identified from a small insert genomic library for Peronospora tabacina. Mycologia 104:633-640.

78. Weir, B. S., and Cockerham, C. C. 1984. Estimating F-statistics for the analysis of population structure. Evolution 38:1358-1370. 